\title{
Interpersonal Realizations of Pedagogic Discourse in Indonesian EFL Classrooms
}

\author{
Sunardi, M. Sri Samiati Tarjana, Soepomo Poedjosoedarmo, Riyadi Santosa \\ Department of Linguistics, Doctoral Program, Universitas Sebelas Maret, Surakarta, Indonesia \\ Email: soenklaten@gmail.com
}

How to cite this paper: Sunardi, S., Tarjana, M. S., Poedjosoedarmo, S., \& Santosa, R. (2018). Interpersonal Realizations of Pedagogic Discourse in Indonesian EFL Classrooms. International Journal ot Language Teaching and Education, 2(3), 205-215.

https://doi.org/10.22437/ijolte.v2i3.5678

Accepted: October 18, 2018

Published: November 30, 2018

Copyright (C) International Journal of Language Teaching and Education.

This work is licensed under the Creative Commons Attribution InternationalLicense (CC BY 4.0).

http://creativecommons.org/licenses/by/4 $.0 /$

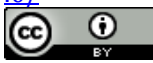

\begin{abstract}
This paper describes the lexicogrammatical realizations of interpersonal meaning in English as a Foreign Language (EFL) classrooms in Indonesian university context. The realizational grammatical patterns are presented using MOOD system in systemic functional linguistics (SFL). The data of this study were three EFL classrooms taken from three English departments in Indonesian universities in Semarang City. Data analyses were done by transcribing the lectures and then divided them into clauses from which the lexicogrammatical realizations of pedagogic MOOD were identified and classified based on MOOD System as suggested by Halliday\& Matthiessen in SFL perspectives. The results of the study show that interpersonally, the clauses used in the EFL classrooms are predominated by declarative clause, interrogative clause, and imperative clause. The predominance of declarative clause is influenced by the teacher-centered teaching method used in the classrooms. This method poses lecturer as an expert and students as novice. In this situation, lecturer dominates in giving information about the learning materials. Besides, interrogative clause is also used by lecturer to know the students' understanding of the learning materials. Finally, imperative clause is also used to ask students to do something relating to the understanding of the learning materials.
\end{abstract}

\section{Subject Areas}

Classroom Discourse Analysis

\section{Keywords}

Interpersonal Meaning, Lexicogrammatical Realization, Pedagogic Discourse, Systemic Functional Linguistics

\section{Introduction}

An English teaching and learning activity can be considered as a genre from the perspective of systemic functional linguistics because the activities are arranged in stages to achieve the teaching and learning goals. Seen as a discourse, such teaching and learning activity is called as a pedagogic discourse (Christie, 1995: 223). The existence of genre characteristics in a teaching-learning episode shows that pedagogic discourse is a structured language behavior (Christie, 2002: 3). One of the structured 
characteristics of a pedagogic discourse is reflected from its overall staged-activities and its linguistic features used in carrying out the teaching-learning activities to achieve the learning objectives. The specific lexicogrammatically features used in each teaching-learning step shows certain meanings communicated in the step. One of the meanings is the interpersonal meaning referring to the social relations between teacher and students in the classroom.

English pedagogic discourse has been the focuses of some studies under systemic functional linguistics (SFL). For example, Christie (1991, 1995), referring pedagogic discourse as a curriculum genre, studied writing planning classrooms and social science classrooms of primary schools in Australia. They found that the schematic structure of the writing curriculum genre was Task Orientation ${ }^{\wedge}$ Task Specification ${ }^{\wedge}$ Task, where ${ }^{\wedge}$ means 'is followed by'. She also found two registers operating in curriculum genre: regulative register and instructional register. Regulative register deals with directing and sequencing the learning activities to achieve the learning goals, while instructional register has to do with learning the instructional content. Another study on English as a second language (ESL) classroom discourse was conducted by Sinar (2002), which focused on the realization of experiential meaning. Reference [4] stated that the lecture discourse was experientially predominated using relational process to focus on the transformation of intellectual values. Another ESL classroom was also studied by Love \& Suherdi (1996), which focused on the realization of interpersonal meaning through the negotiation of knowledge between teacher and students in letter writing classroom. It was found that in the phase of establishing a context of shared experience, students were the Primary Knower, while teacher was the Secondary Knower; in the phase of explaining the schematic structure and the language features of the text, teacher was the Primary Knower, while students were the Secondary Knower; and in the phase of review, teacher was the Primary Knower, while students were the Secondary Knower.

Nevertheless, the above study on interpersonal meaning realization as stated in Love \& Suherdi (1996) focused on the classroom of English as second language in Australian context. The interpersonal relationship between teacher and students in this study was portrayed by using exchange structure during the negotiation of knowledge and action in the classroom. So far, no study of interpersonal meaning realization of EFL classroom in Indonesian context is ever conducted. Some EFL classroom studies in Indonesian context in the literature include Emilia (2005) and Wiratno (2018), which focus more on student's ability in producing certain text type or genre, i.e. argumentative and news genres. They do not describe the lexicogrammatically features of how teacher and students interact in unfolding the classroom discourse. That is why, the present study describes the lexicogrammatically realization of interpersonal meaning as one of the multifunctional meanings exchanged in EFL classroom in Indonesian context. The realizationally pattern is presented by using MOOD system network in SFL as stated by Matthiessen (1995) and Halliday \& 
Matthiessen (2014).

\section{Literature Review}

\subsection{Metafunctions}

SFL is a theory of language which perceives language as social semiotics: language is used to accomplish everyday social life (Eggins, 2004: 2). Language is viewed as a resource for making not just one meaning at a time, but three strands of meanings simultaneously (Eggins \& Slade, 1997: 48). These three types of meaning are referred to as metafunctions (Martin, 2009: 11). So, there are three metafunctional meanings language represents in its use in social interaction: ideational, interpersonal, and textual (Matthiessen, 1995: 47). Language-in-use represents ideational meaning because whatever it is used for, it construes human experience. Ideational meaning falls into two: experiential and logical meanings. Experiential meaning construes linguistic unit as representation of a process and its related participants and circumstance, while logical meaning refers to the interdependency and logico-semantic relation of one linguistic unit to the others. Besides ideational meaning, language-in-use also represents interpersonal meaning at the same time. It is the meaning that enacts language user's personal and social relationships with the other people around him/her. Finally, the third meaning represented by language-in-use is textual meaning, that is, the meaning referring to the construction of ideational and interpersonal meanings as a message into a cohesive text.

In social interaction, the metafunctional meanings (discourse semantics) are realized through the choice of words and their order (lexicogrammar), which is in turn realized through phonology/graphology. Martin (2009: 12) presents the realizations of these levels of language in meaning-making system as in Figure 1.

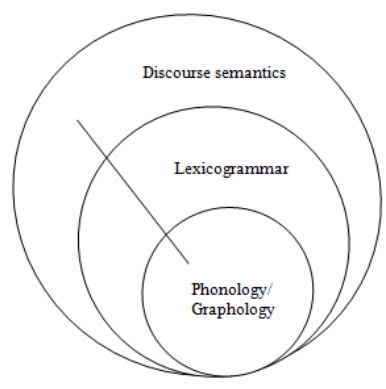

Figure 1. Levels of language

Because the focus of this study is only the interpersonal meaning, this paper only discusses the lexicogrammar system for realizing the interpersonal meaning. As stated by Eggins \& Slade (1997: 53-54), there are four main types of lexicogrammatical patterns which represent and enact the social relationships of participants in interaction. These patterns include the uses of MOOD of clauses, the attitudinal and 
expressive lexis, the speech functions, and the generic structures. This paper only focuses on the realization of interpersonal meaning through the lexicogrammatically patterns of MOOD of clauses used in the discourse under study.

\subsection{MOOD System}

The term MOOD refers to the primary interpersonal system of clauses by considering the occurrence of functional Mood elements of Subject and Finite in a clause. According to this system, a clause is considered to consist of two functional elements: Mood and Residue. Mood is the combination of functional constituents of Subject and Finite of a clause, while Residue is the combination of Predicator, Complement, and Adjunct of a clause. Halliday \& Matthiessen (2014: 24) classify English clauses as three basic types of interact, as stated in Figure 2.

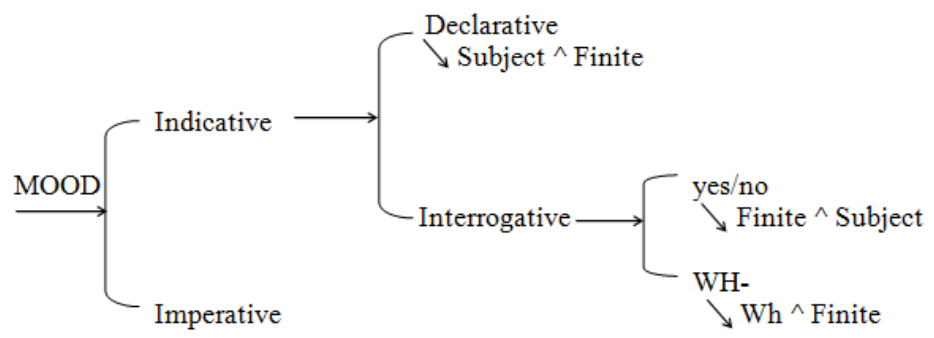

Figure 2. MOOD system

As Figure 2 shows that there are two major types of English clause: indicative clause and imperative clause. Indicative clause is concerned with the exchange of information (the negotiation of propositions), while imperative clause is concerned with the performance of an action to provide a service or to exchange goods (the negotiation of proposals). Within indicative clauses, there are interrogative clause which concerns the demanding of information and declarative clause which concerns the giving of information. Interrogative clause can be divided any further into yes-no interrogative for polar question and why-interrogative for content question.

MOOD type of a clause has to do with the occurrence and sequence of certain negotiable elements of clause structure. Each MOOD type involves a different configuration of a set of basic clause constituents. Full English clause consists of some functional elements: Subject, Finite, Predicator, Complement, and Adjunct. Of these elements, Subject and Finite constitute pivotal constituents of a clause. Egging (2004) and Butt, et al. (2001) define the functional elements of a clause as the following. Subject is the person or thing which becomes the concern of the clause. Subject is generally realized by a nominal group. Finite is the part of the verbal group in the clause which shows tense, modality, and polarity. In a clause with a verbal group consisting 
of more than one word, the Finite is the first element in the verbal group. Predicator is the other part of the verbal group in the clause which describes the action or process involved in the clause. In a clause with a verbal group consisting of only one word, the word functions as both Finite and Predicator. Complement is the participant which is somehow implicated in the clause but is not pivotal participant. Complement is also realized by a nominal group. Finally, Adjunct is an element which adds extra information about the events expressed in the clause through circumstantial, interpersonal, or textual information. Adjunct is typically realized by adverbial group or prepositional phrase.

In terms of the presence of Mood elements, a clause can be declarative, interrogative, or imperative. A declarative clause is clause in which the Subject occurs before the Finite (Subject ${ }^{\wedge}$ Finite, where ${ }^{\wedge}$ means 'is followed by'). The following clause is an example of declarative clause.

(1) We will distinguish first the characteristics of the five phrases.

\begin{tabular}{|c|c|c|c|c|}
\hline we & will & distinguish & first & the characteristics of the five phrases. \\
\hline Subject & Finite & Predicator & Adjunct & Complement \\
\hline \multicolumn{2}{|c|}{ Mood } & \multicolumn{3}{c|}{ Residue } \\
\hline
\end{tabular}

An interrogative clause is a clause in which the Finite precedes the Subject. There are two types of interrogative clause: yes/no interrogative and wh-interrogative. The following clauses are examples of interrogative clauses.

(2) Do you find adjective phrase in this sentence?

\begin{tabular}{|c|c|c|c|c|}
\hline Do & you & find & adjective phrase & in this sentence? \\
\hline Finite & Subject & Predicator & Complement & Adjunct \\
\hline \multicolumn{2}{|c|}{ Mood } & \multicolumn{3}{|c|}{ Residue } \\
\hline
\end{tabular}

(3) What do you find in this sentence?

\begin{tabular}{|c|c|c|c|c|}
\hline What & do & you & Find & in this sentence? \\
\hline Complement & Finite & Subject & Predicator & Adjunct \\
\hline \multirow{4}{|c|}{ Mood } & \multicolumn{2}{c}{ Residue } \\
\cline { 2 - 4 }
\end{tabular}

Imperative clause is a clause which typically does not contain the elements of Subject or Finite but consists of only a Predicator, plus any of the non-core participants of Complement and Adjunct. The following is an example of imperative clause.

(4) Find an adjective phrase in this sentence.

\begin{tabular}{|c|c|c|}
\hline Find & an adjective phrase & in this sentence. \\
\hline Predicator & Complement & Adjunct \\
\hline \multicolumn{3}{|c|}{ Residue } \\
\hline
\end{tabular}

\section{Method}

The data of this study were video-taped English lectures taken from three English departments in some Indonesian universities where English was used as a foreign 
language (EFL). There were three EFL classrooms analyzed in this study, which were coded as Genre-1, Genre-2, and Genre-3. The lecturers of these genres were non-native English speakers. When the genres were video-taped, the classes talked about content lessons in English language, such as English phrases, English clauses elements, and translation strategies. In addition, the learning method employed by the lecturers in the three genres was conventional method.

Data analyses were done by transcribing the lectures by referring to the transcription symbols as suggested in Eggins \& Slade (1997). To get the validity of the lecture transcriptions, they were consulted to the lecturers to make sure that the transcriptions transcribed the real utterances of the lectures. The transcribed utterances were then divided into clauses from which the lexicogrammatically realizations of pedagogic MOOD were identified and classified based on MOOD system network as suggested by Matthiessen (1995) and Halliday \& Matthiessen (2014).

\section{Findings and Discussion}

Based on the identification of the clause types used in the three genres under study, the MOOD types can be presented in Table 1 .

Table 1. The MOOD types used in the EFL classrooms

\begin{tabular}{clcccccc}
\hline & & \multicolumn{2}{c}{ Genre-1 } & \multicolumn{2}{c}{ Genre-2 } & \multicolumn{2}{c}{ Genre-3 } \\
\cline { 3 - 8 } No & Clause type & $\mathrm{N}$ & $\%$ & $\mathrm{~N}$ & $\%$ & $\mathrm{~N}$ & $\%$ \\
\hline 1 & Minor clause & 35 & & 2 & & 4 & \\
2 & Declarative: full & 367 & 49.4 & 346 & 32.0 & 362 & 54.6 \\
3 & Declarative: elliptical & 106 & 27.7 & 556 & 51.5 & 183 & 27.6 \\
4 & Yes/no interrogative: full & 36 & 4.8 & 16 & 1.5 & 49 & 7.4 \\
5 & Yes/no interrogative: elliptical & 29 & 3.9 & 37 & 3.4 & 24 & 3.6 \\
6 & Wh-interrogative: full & 58 & 7.8 & 20 & 1.9 & 18 & 2.7 \\
7 & Wh-interrogative: elliptical & 14 & 1.9 & 78 & 7.2 & 9 & 1.4 \\
8 & Imperative: full & 27 & 3.6 & 25 & 2.3 & 17 & 2.6 \\
9 & Imperative: elliptical & 6 & 0.8 & 2 & 0.2 & 1 & 0.2 \\
& & 743 & 100 & 1080 & 100 & 663 & 100 \\
\hline
\end{tabular}

\subsection{Minor Clauses}

Genre-1 uses more minor clauses compared to Genre- 2 and Genre-3. In Genre-1 there are 35 minor clauses used by lecturer and students in learning activity, while in Genre- 2 and Genre-3 there are successively only 2 and 4 minor clauses. In the three EFL classrooms, minor clauses are more frequently used by lecturer than students. The minor clauses are commonly used by the lecturer at the beginning of the lecture (greeting) and at the end of the meeting for leave taking. Additionally, minor clauses are also used for filler when explaining the learning materials to the students or used for feedback. Some minor clauses used in the EFL classrooms can be exemplified in Table 2 . 
Table 2. Some minor clauses used in the EFL classrooms

\begin{tabular}{clll}
\hline Genre & Speaker & Clause no & Minor clauses \\
\hline Genre-1 & Lecturer & 1 & Good evening everybody \\
& Student & 2 & Good evening sir \\
& Lecturer & 106 & Come on! \\
& Lecturer & 203 & Okay? \\
& Lecturer & 204 & Okay \\
& Lecturer & 497 & Okay \\
& Lecturer & 790 & Bye bye \\
& Student & 791 & See you \\
Genre-2 & Lecturer & 1 & Ok. Uhm, good afternoon, class \\
& Student & 2 & Good afternoon \\
& Lecturer & 1 & Okay so good evening everybody \\
& Student & 2 & Good evening \\
& Lecturer & 714 & Bye \\
& Student & 715 & Bye sir \\
\hline
\end{tabular}

\subsection{Declarative Clause}

In terms of using declarative clause in the classrooms, lecturer dominates in using declarative clauses compared to the students. For example, in Genre-1 the lecturer used 482 declarative clauses (15.9\%); in Genre-2 the lecturer used 688 declarative clauses (76.3\%); and in Genre-3 the lecturer used 214 declarative clauses (23.7\%). This shows the fact that lecturer is more dominant in giving information concerning with learning activity. Lecturer's predominance in using declarative clauses in the genres has something to do with the role relationships or tenor between lecturer and students. There is unequal power shared by lecturer and students. This happens partly because of the learning method employed in the genre, which is a conventional method where lecturer is considered as the center of the teaching-learning activities. In this lecturer-centered method, lecturer is positioned as an expert, that is, a person who is more experienced in and has more accesses to the learning materials. On the other hand, students are positioned as a novice, that is, a person who is new in or inexperienced in the learning materials. In the teaching-learning activities, lecturer is responsible to transfer the knowledge to the students, while students mostly listen and understand lecturer's explanations. In the system of clause as exchange, lecturer takes a speech role of giving, and the commodity exchanged is information. The combination of speech role 'giving' and commodity 'information' makes a speech function of statement or the act of giving information [14]. In MOOD system, a clause which is used to give information is a declarative clause, which is signified by the presence of 
the Subject before the Finite. The following are some declarative clauses used in the EFL classrooms.

(5) The possibilities of the phrase that we can make or that we can produce will be one of the five phrases.

\begin{tabular}{|c|c|c|c|}
\hline $\begin{array}{l}\text { The possibilities of the phrase } \\
\text { [ithat we can make or that we } \\
\text { can produce] }]\end{array}$ & will & be & one of the five phrases. \\
\hline Subject & Finite & Predicator & Complement \\
\hline Mood & \multicolumn{2}{|c|}{ Residue } \\
\hline
\end{tabular}

(6) It can be a noun phrase, adjective phrase, adverb phrase, verb phrase, or prepositional phrase.

\begin{tabular}{|c|c|c|l|}
\hline It & can & be & $\begin{array}{l}\text { a noun phrase, adjective phrase, adverb } \\
\text { phrase, verb phrase, or prepositional } \\
\text { phrase. }\end{array}$ \\
\hline Subject & Finite & Predicator & Complement \\
\hline \multicolumn{2}{|c|}{ Mood } & \multicolumn{2}{c|}{ Residue } \\
\hline
\end{tabular}

(7) The phrase the five students talks about students.

\begin{tabular}{|c|c|c|c|}
\hline The phrase the five students & \multicolumn{2}{|c|}{ talks about } & students \\
\hline Subject & Finite & Predicator & Complement \\
\hline \multicolumn{2}{|c|}{ Mood } & & Residue \\
\hline
\end{tabular}

\subsection{Interrogative Clause}

The second dominant clause used by lecturers in the EFL classroom under study was interrogative clause, both yes/no interrogative and wh-interrogative. Wh-interrogative clauses were used more (52.5\%) than yes/no interrogative clauses (47.5\%). The lecturers used interrogative clauses for demanding information from the students. Lecturer's use of interrogative clause in the classroom is also influenced by his/her higher power in relation to students. As the center of the teaching-learning activities, lecturer's responsibilities include both transferring knowledge to students and ensuring students' understanding of the learning materials. In the system of clause as exchange, lecturer does not only give information concerning the topic discussed in the classroom but also demands information from the students to know the extent of their understanding of the learning materials. In other words, lecturer should use both speech functions of statement and question. In MOOD system, speech function of question is realized through interrogative clause, which is signified by the Mood structure of Finite Preceding Subject.

To demand information from students, lecturer used both why-interrogative and yes/no interrogative. The more frequently used wh-interrogatives rather than yes/no interrogatives in the classroom have something to do with lecturer's responsibility to guarantee students' understanding of the learning materials. Wh-interrogative clause is an interrogative clause consisting of wh-question word, such as what, who, when, 
how, etc. The use of wh-question word is to probe for a missing element of clause structure (Eggins \& Slade, 1997: 87). For example, when probes for a circumstantial adjunct, who probes for the Subject, and what probes for either Subject or the Complement of a clause. In classroom context under study, lecturer used wh-interrogative to get detailed information about the parts of the learning materials already understood or not yet understood by students. Such information cannot be provided by using yes/no interrogative clause, because yes/no interrogative clause demands only a yes or no response from students without further information about the response. To elicit additional information, lecturer used an interrogative clause by using a whquestion word to probe for the intended additional information.

Table 3 presents examples of yes/no interrogative and wh-interrogatives clauses used in the EFL classroom. $\mathrm{L}$ is for lecturer and $\mathrm{S}$ is for student.

Table 3. Examples of yes/no interrogative and wh-interrogative clauses

\begin{tabular}{lll}
\hline Speaker & Clause & MOOD \\
\hline $\mathrm{L}$ & $\begin{array}{l}\text { Okay, for example, I have a sentence like } \\
\text { this: The students in this class are stud- } \\
\text { ying English everyday. } \\
\text { [L writes the sentence on the white } \\
\text { board]. } \\
\text { Do you think that the sentence has a } \\
\text { noun phrase? }\end{array}$ & \\
& Yes. & Yes/no interrogative \\
$\mathrm{S}$ & Yes. & Declarative: elliptical \\
$\mathrm{L}$ & What is it? & Declarative: elliptical \\
& The students. & Wh-interrogative \\
$\mathrm{S}$ & The students. & Declarative: elliptical \\
$\mathrm{L}$ & Okay, that's right. & Declarative: elliptical \\
& The students is a noun phrase & Declarative: full \\
& & Declarative: full \\
\hline
\end{tabular}

As examples in Table 3 show that to know students' understanding of the concept of noun phrase discussed in the classroom, lecture gave an example of sentence and made a question about the sentence. Firstly, a yes/no interrogative clause was used to know if there was a noun phrase in the sentence. The yes/no question was responded by students with 'yes', telling that they found a noun phrase in the sentence. The answer 'yes' by students did not inform the facts that they really identified the intended noun phrase. Then, a further question with what question word was used to ensure that students could identify which phrase in the sentence was the intended noun phrase. This wh-interrogative clause was answered by students by saying 'the students'. The answer ensured lecturer that students really understood the concept of noun phrase and could identify a noun phrase in a real use. Some other interrogative clauses used in the EFL classrooms are exemplified in the following examples:

(8) Do you find adjective phrase? 


\begin{tabular}{|c|c|c|c|}
\hline Do & you & find & adjective phrase? \\
\hline Finite & Subject & Predicator & Complement \\
\hline \multicolumn{2}{|c|}{ Mood } & \multicolumn{2}{|c|}{ Residue } \\
\hline
\end{tabular}

(9) What is the type of this phrase?

\begin{tabular}{|c|c|c|}
\hline What & is & the type of this phrase? \\
\hline Complement & Finite & Subject \\
\hline Residue & \multicolumn{2}{c|}{ Mood } \\
\hline
\end{tabular}

\subsection{Imperative Clause}

Another clause type which is frequently used in the EFL classrooms is imperative clause. The use of imperative clause in the classroom is also influenced by the role relationships between lecturer and students. As the center of the teaching-learning activities, lecturer is responsible for students' understanding of the learning materials. In this context, lecturer is entitled to ask students to do something in relation to understanding the learning materials. In the system of clause as exchange, lecturer uses speech function of command, the combination of speech role 'giving' and commodity exchanged 'goods \& services'. In the MOOD system, command is congruently realized by an imperative clause.

Full imperative clauses are more frequently used in the classrooms than the elliptical imperative clauses. This is done for the clarity of command given to the students. The clarity of the command will decrease when commands are stated by using Predicator only without Complement and Adjunct. Some imperative clauses used in the classrooms are presented in Table 4.

Table 4. Some imperative clauses used on the EFL classrooms

\begin{tabular}{|c|c|c|c|c|}
\hline No & Predicator & Complement & Adjunct & Clause type \\
\hline 1 & Find & $\begin{array}{l}\text { an adjective, for } \\
\text { example clever: }\end{array}$ & & Imperative: full \\
\hline 2 & Make & another word & $\begin{array}{l}\text { in front of the word } \\
\text { clever. }\end{array}$ & Imperative: full \\
\hline 3 & Pay & attention & $\begin{array}{l}\text { to the words very beau- } \\
\text { tifully. }\end{array}$ & Imperative: full \\
\hline 4 & Pay & attention & $\begin{array}{l}\text { to the combination of } \\
\text { the words will, have, } \\
\text { and attended. }\end{array}$ & Imperative: full \\
\hline 5 & Remember & & & Imperative: elliptical \\
\hline 6 & Read & & & Imperative: elliptical \\
\hline
\end{tabular}

As the examples in Table 4 show that lecturer uses imperative clause to require students to do an action in relation to understanding the learning materials. The intended action is realized by Predicator in material processes, such as find, make, give, analyze, or mental processes, such as pay attention, remember, accompanied by Complement referring to things concerning the learning materials, such as an adjective, another word, the words 'very beautifully', the clause structures, your work, your partner's work.

\section{Conclusion}


Interpersonally, the clauses used in the EFL classrooms are predominated by declarative clause, interrogative clause, and imperative clause. The predominance of declarative clause is influenced by the teacher-centered teaching method used in the classrooms. This method poses lecturer as an expert and students as a novice. In this situation, lecturer dominates in giving information about the learning materials. Besides, interrogative clause is also used by lecturer to know the students' understanding on the learning materials. Finally, imperative clause is also used to ask students to do something concerning understanding the learning materials.

\section{References}

[1] Butt, D., Fahey, R., Spinks, S., \& Yallops, C. (2001). Using functional grammar: An explorer's guide (Second edition). Sydney: NCELTR, Macquarie University.

[2] Christie, F. (1991). Pedagogical and content registers in a writing lesson. Linguistics and Education, 3: 203-224.

[3] Christie, F. (1995). Pedagogic discourse in the primary school. Linguistics and Education, 7: 221-242.

[4] Christie, F. (2002). Classroom discourse analysis: A functional perspective. London: Continuum.

[5] Eggins, S. (2004). An introduction to systemic functional linguistics. Second Edition. London: Continuum.

[6] Eggins, S., \& Slade, D. (1997). Analyzing casual conversation. London: Cassel.

[7] Emilia, E. (2005). A critical genre-based approach to teaching academic writing in a tertiary EFL context in Indonesia (Ph.D. thesis, University of Melbourne, Australia). Retrieved from https://minerva-access.unimelb.edu.au/handle/11343/39548

[8] Halliday, M.A.K., \& Matthiessen, C. (2014). Halliday's introduction to functional grammar (fourth edition). London: Routledge.

[9] Love, K., \& Suherdi, D. (1996). The negotiation of knowledge in an adult English as a second language classroom. Linguistics and Education, 8: 229-267.

[10] Martin, J.R. (2009). Genre and language learning: A social semiotic perspective. Linguistics and Education, 20: 10-21.

[11] Martin, J.R., Matthiessen, C.M.I.M, \& Painter, C. (2010). Deploying functional grammar. Beijing: The Commercial Press.

[12] Matthiessen, C.M.I.M. (1995). Lexicogrammatical cartography: English systems. Tokyo: International Language Sciences Publishers.

[13] Sinar, T. S. (2002). Phasal and experiential realizations in lecture discourse: A systemic functional perspectives. (Ph.D. thesis, Faculty of Languages and Linguistics, University of Malaya, Malaysia). Retrieved from http://studentsrepo.um.edu.my/id/eprint/232

[14] Wiratno, T. (2018). Teaching news writing in English: From genre to lexicogrammar. Pertanika Journal of Social Sciences \& Humanities, 26 (2): 909 - 928. 